\title{
Theological Aspect on Ijtihad of M. Arsyad Thalib Lubis' Thought
}

\author{
Sugeng Wanto ${ }^{1,2}$, Prof. Hasyimsyah Nasution ${ }^{2}$, Prof. Nawir Yuslem ${ }^{2}$ \\ ${ }^{I}$ Ph.D Student at State Islamic University of North Sumatra (UINSU), Medan, Indonesia \\ ${ }^{2}$ Lecturer at State Islamic University of North Sumatra (UINSU), Medan, Indonesia
}

\begin{abstract}
Islam is a religion that has two main aspects, namely aqidah (belief) and shari'ah. These two aspects cannot be separated from one another. The connection is not only on the form of practice, but also on the fundamentals of developing thought. Ijtihad having special meaning in Islam is to use all abilities as maximum as possible to obtain syara'(Lord's rule) law through the use of recognized syara' law. Ijtihad of H.M. Arsyad Thalib Lubis covers many fields such as the field of Islamic law (figh), theology and the benefit of the people (life). Special thought of H.M.Arsyad Thalib Lubis about Islamic law (figh) has a pattern of Indonesian. So that becomes islamic fiqh Indonesia.
\end{abstract}

Keywords: Al Quran; theology; ijtihad; M. Arsad Thalib Lubis

\section{INTRODUCTION}

Islam is a religion that has two main aspects, namely aqidah (belief) and shari'ah. These two aspects cannot be separated from one another. The connection is not only on the form of practice, but also on the fundamentals of developing thought. In the beginning, the term of syari'at has a broad meaning, it is not only meant as jurisprudence (fiqih) and law, but it includes also as aqidah and everything that Lord commands. Thus, the Shari'ah implies of acknowledging the oneness of Lord, obeying Him, believing in His Messengers, His holy books, the day of vengeance and everything that makes someone becomes true Muslim. The meaning of shari'ah is understood in a limited way, namely in the sense of jurisprudence and identical with Islamic law, so the term of syari'at is not understood anymore with its previous broad meaning because it seems as if identical is with the term of fiqihI (Islamic law) that is in contrast to the Islamic belief.

Likewise the term of fiqh before having in a limited sense of the terminological meaning (ma'na $i_{i}{ }^{-} i l \pm$ hiyah), it encompasses the broad meaning of tafaqquh fi ad-d $d^{3} n$ which encompasses all aspects of understanding of Islamic teachings. Hence we see the essay of Imam Abu Hanifa $(\mathrm{w} 150 \mathrm{H})$ in figh al-Akb $\pm r$, it does not contain the fiqh material that we know in other figh books, but it rather contains the material of faith. this case shows that the word ijtihad can also be used on terms besides of fiqh. Jurisprudence in the terminological sense that has been established as a science in the second century by Ibn Khaldun $(\mathrm{d} .808 \mathrm{H})$ is categorized as minal ulm had ${ }^{3}$ sati $f^{3}$ millah (including the category of modern science in religion). The elements forming this science are the Qur'an (Korab), Sunnah, Ijma 'and the interpretation of the theologian (ijtihad). The aim of this science is af ' $\pm l$ al-mukallaf' $n$, in other words the target is human and society. Behavior, human activities and the dynamics of society are a real picture of af ' \pm l al-mukallaf $n$ in the framework of the establishment of diverse life and a virtuous society. The interrelatedness of fiqh in the context of real and dynamic life is more readable when we explore ways of interpretation (in Islamic law terms called Ushul Figh) linking a law with its contextual background. That is contextual conditions considered in determining Islamic law.Theologians who are from the period of Companions of the Prophets until Fukoha 'mutaakhirin never cease in developing the science of fiqh after the tasyri period 'ends with the death of the Prophet and then continued with the tadwin period (codification) where the elements of fiqh begin to be processed by the method of ijtihad developing the ijma', Qiyas and istiqra. then, in the period tahzib the systematic is perfected and undergoes some reformulation to freezing format (taklid).

In developing the comprehension of various law cases, the theologian use various methods and approaches. One of them is the theological approach based on the existence of the relationship between aqidah and shari'ah, so it influences the determination of the law. The theological approach will offer in understanding and developing toward the understanding of the teachings more advanced, broad and philosophical. therefore, $\mathrm{M}$. Arsyad Thalib Lubis makes theology as one of the important elements based on his law thinking or theological aspects greatly affecting his method of ijtihad. Thus, his ijtihad method will contribute to Moslems in understanding the growing diversity. 


\section{METHODOLOGY}

The word Ijtihad comes from the word al-juhd, which means al-qah (power, ability, energy) or from the word al-jahd which means al-Masyaqqah (difficulty). Therefore, according to the meaning of language ijtihad means "badzl al-wus' wa al-majhd" (the mobilization of power and ability), or "the mobilization of all power and ability in an activity of hard and difficult activities." Based on the linguistic sense there are two main elements in ijtihad: (1) power or ability, (2) difficult and hard objects. Power or ability here can be applied generally, which includes physical-material, mental, and intellectual power. Ijtihad as a scientific terminology in Islam is also inseparable from the two elements where scientific activity relies more on intellectual activity, so the meaning of ijtihad refers more to the exertion of intellectual ability in solving various difficulties faced by both the individual and society. In summary, ijtihad means real or works hard to get something. ijtihad that is based on terminology, Imam syaukani gives meaning of ijtihad by mobilizing all effort in acquiring skills in Islamic law by practicing of istinbat way. Basically, ijtihad having special meaning in Islam is to use all abilities as maximum as possible to obtain syara'(Lord's rule) law through the use of recognized syara' law. In other definition, ijtihad is the mobilization of all the willingness by a jurist or a mujtahid to acquire knowledge about syara law. According to Fazlur Rahman, ijtihad refers to the striving of the jurists to the point of mental exhaustion to derive principle and rules of law from evidence found in the sacred texts of sources. According to

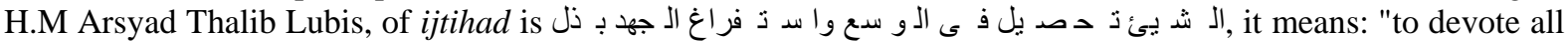
the ability or the loads of trouble to obtain something", the word al-jahd (الد (لد (ل) means difficult, and it is not used on the words al-ijtihad \pm except on anything that contains difficulties, as in the sentence:

Meaning: "he sincerely devotes his energy to lift the grinding stone" According to the terms of Ushul Fiqihh expert, there are many diverge definitions. Perhaps the definition of ijtihad is closer to the intent of ijtihad where it is the definition of al-Amidi in his book Al-Ihkam fi Usul al-Ahkam:

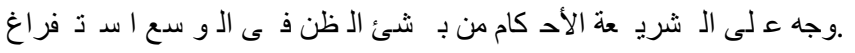

Meaning: "devoting all the ability to produce the zero theorem becomes one form.

H. M. Arsyad Thalib Lubis also writes in his book Al-Usul Min 'Ilm Usul that the terms of ijtihad is

as follows:

Meaning: "devoting every effort of a faqih to know syara' law of theorems. It seems that ijtihad contains seriousness. the people who fight of ijtihad means he really expresses his opinions in various fields of the exiested theorem. H.M. Villanueva Thalib Lubis thinks that in his period there a condition is too easy to classify someone as bid'ah dholalah. this certainly have to go through deep or earnest thought to resolve a case. Thus, ijtihad, in his view is by putting all ability of someone.

During the lifetime of Prophet, he never has case that misses of his attention. The laws are fully regulated by the provisions of revelation, both texts of Qur'an and Sunnah. the law that is in certain condition made by the friends without the direct guidance of nash (Qur'an), especially in cases that occur outside of Medina, is immediately reported to him to get determination, so even if sometimes they fight the ijtihad, the final decision is on the hands of the Prophet. this situation changes soon after the Prophet Muhammad passes away. because there are no other references, rule or decision of the friends that becomes top position in the decision law. every cases that has been set previously, they always heed the provisions of nash (the texts od Qur'an). However, if faces wto new cases, they have to be able to find the law of the instructions given indirectly by the texts of Qur'an and Sunnah. These efforts are known as ijtihad.

There are several important points contained in ijtihad, namely:

A. Ijtihad is mobilizing all potential or ability as maximum as possible.

B. Ijtihad can only be done by someone who is competent in their field.

C. Ijtihad is done to obtain a strong assumption of Islamic law.

D. The effort of ijtihad is done istinbath (the efforts make the decision of islamic law based on Qur'an and Sunnah).

When the Prophet sends Mu'adh ibn jabal to Yemen as judge, he asks Mu'adh: "what will you if you get a case that have to be decided?" Mu'adh said: I will make a decision based on the Koran (Qur'an). The Prophet asked: what will you if you do not find in it. Mu'adh replied by as-Sunnah ". The Prophet asked, how if do not find both?. Mu'adh said: I would interpret Islam in my mind, I will not let case without the law, then the prophet taps my chest and says: Praise to Allah that has given to you guidance ." Umar ibn Khattab, one of his friends who is the most in interpreting the law at the companions time. Example: the whip laws for drunkard, at the prophet period it is only 40 time s of whip but at Umar period increased to 80 times, that is because the society does not take the lesson of 40 whips, so Umar decides so that the whip impacts to the society and contains a deterrent effect.

Etymologically, as explained by asy-Syauk which is also quoted by M. Arsyad Thalib Lubis, he means the word ijtihad as a derivation of the word "al-juhd" which has the meaning of energy, ability, power (aaaqah) or from the word " Al-jahd "which means an action done with difficulty (masyaqqah). Therefore, ijtihad means the mobilization of power and capability or the mobilization of all power and ability in hard and difficult activities. 
In the other terms, according to asy-Syauk ijtihad is to put the ability of mujtahid (someone who fight in Islamic law) in an effort to find Islamic law that is operational ('amali) by way of istinba ${ }^{-}$. "

In term of ijtihad, a mujtahid must have the qualified determination and ability to ijtihad, so the theologian has decideded a set of requirements that must be done by mujtahid. Competence of mujtahid will be highly correlated with the results of ijtihad where the meaning of ijtihad itself is devoting all ability or potential to decide a law. This means to do it optimally. that is why certain requirements are needed in ijtihad, because indeed it is the most important principle of islamic law. with ijtihad, Islamic law can solve various problems of the Muslims based on the development of time and place. M. Iqbal said that ijtihad is the principle of movement in Islam that makes Islamic law to be dynamic. The requirements that have agreed and disputed, H. M. Arsyad Thalib Lubis says that the requirement that are generally owned by mukallaf who allows it to decide the Islamic law of the theorem to know the laws, and the law is impossible decided except for those who know the general requirements. Here are the requirements that must be on mujtahid:

a. Understanding the texts of the Qur'an and Sunnah

To know nash of Koran and the Sunnah for the mujtahid is a requirement agreed upon by the theologian, they disagree about how far the intensity and capacity of knowledge (ma'rifah) toward the Qur'an and the Sunnah. The question arises and a mujtahid understands all contents of the Qur'an and Sunnah.

According to H. M. Villanueva Thalib Lubis, the meaning of understanding the Koran and the Sunnah is to know and understand the verses of law and hadist (deed or story of prophet) of law, not all the content of the Qur'an and the Sunnah.according to ash-Syaukani, a mujtahid must know nash although the Qur'an and Sunnah, but they do not have to know the entire contents of both. For ash-Syaukani, a mujtahid needs to know nash relating with the laws of the Qur'an and Sunnah.

\section{DISCUSSION}

One special thing of Ijtihad method of H. M.Arsyad Thalib Lubis is the theological pattern in his thinking. There three important things that becomes the focus of this research before explaing about the theology, they are, the oneness of Lord, qadim of Koran and Qada 'and Qadar of lord.

\section{The Theology Concept of Sunni of Al-Ash'ari and Al-Maturidi: a. The Oneness of Lord}

Almost all theologians including al-Ash'ari agree that Allah is the One Lord, but the definitive study of the oneness of Lord often gets differences of opinion among them. about the oneness of Lord, al-Ash'ari proclaimes the creation of the universe from nothing into existence where definitely have been created by Almighty Lord, the Knowing, Almighty, the Speaking, the Hearing. this statement have implications for the assertion that Lord has several traits whose logical consequences where will gather between substance and traits on the existence of Lord. In other word, the other term will emerge ta'add al-qudama '. Lord is the one. To prove the oneness of Lord, al-Maturidi gives the reason for the creation of the universe that is created by the One Lord. as heard derived from the Qur'an certainly shows that Lord is one. if rationalized by reason, the conclusion is the same, Lord is the One. if the universe is created by two Lords that have a different will, this world will be broken and destroyed. If the will is the same, Lord is not The Almighty .Therefore, Lord is the Great unity.

Although Lord is the One, it does not mean that Lord has no traits. According to al-Maturidi, Allah has the traits of Qadim as follows: 1) Nafsiyah (form), 2) Ma'ani (Qadian, Muridan, Hayyan, Sami'an, Basiran, and Mutakalliman), 3) Ma'nawiyah (Qudrah, Iradah, 'Ilm, Hayah, Sama', Basar, and Kalam), 4) Dhatiyah (in the form of hands, face, and eyes). Therefore, al-Ash'ari asserts that the traits of Lord are not Lord and not besides Lord (lahiya huwa wa lahiya ghayruhu). The traits of Lord do not reduce the perfection of Lord at all. The logical reason is that the traits of Lord are not the same as the characteristics of human being.In addition, alAsh'ari in behaving the mutashabihat verses relating to the face of Lord, the hand of Lord, and the eyes of Lord do not interprete as the al-Mu'tazilah does. Al-Ash'ari mantains its original meaning by making it as "bila kayfa" trait where the traits that need not be rationalized and interpreted further. Therefore, according to alAsh'ari, Lord is the great unity with the following characteristics: 1) wujud (nafsiyah), 2) Qadada, Muridan, 'Aliman, Hayyan, Sami'an, Basiran, and Mutakalliman (Called Ma'ani), 3) Qudrah, Iradah, 'Ilm, Hayah, Sama', Basar, and Kalam (called Ma'nawiyah), 4) Wajhun, Yadun, Ayn (called bi laKayfa).

Talking about theology essentially discusses the "oneness of God", and this is fundamental to all existing religions. According to H.M.Arsyad Thalib Lubis, the duties of all prophet sent by Lord to all human beings are the same that is to invite his people to always acknowledge Lord and not worship besides Allah. Next H.M.Arsyad Thalib Lubis explains that: "Islam forbids compering Lord with anything. People who compares Lordor say three Lords, the third God, than three is infidels. "To prove it, H. M. Arsyad Thalib Lubis quotes several verses of the Qur'an such as Surat al-Mukminun verse 23, Hud verse 50, Hud verse 84, Surah Hud verse 61, Surah Al-Maidah verse 72, Surah al-Anbiya 'verse 25. According to H.M. Arsyad Thalib Lubis, the above 
verses expressly state that Lord is One, there is no Lord other besides Allah. Each prophet who has been sent by Lord has taught that Lord is One.

\section{b.Qadim of the Qur'an}

Al-Ash'ari asserts that the Qur'an is the word of Allah while the word of Allah is qadim. Therefore the Qur'an is not human being. This opinion at once criticizes the dissent of the Mu'tazila that the Qur'an is a creature. He gives the excuse that "when Lord wants something, then says kun fa yakun or kunibardan wa salam to the fire, so the Word of Lord here is not kun or kuni because both are addressed to something. While the Word of Lord is the Qur'an itself which is also the traits of Lord, and the traits of Lord is Qadim. Another reason, according to al-Ash'ari, all the names of Lord are explicitly mentioned in the Qur'an. The al-Ash'ari theology asserts that these names are Qadim and not creature.

The Qur'an is the words of Allah while the words of Allah are Qadim as His substance. Therefore, the Quran which is the words of Allah is not a creature as stated by the Mu'tazilah clan. According to al-Maturidi, to know the Qadim of the Qur'an is needed hearing and mind. Hearing is obtained through many media including from the explanation of the Qur'an. To know the truth obtained from hearing, mind has an important role, because it is able to know the good and bad something. Meanwhile, to know more about the Qadim of Qur'an, it is needed the tasted media, news, and thinking. the proof of the Qadim of the Qur'an is the miracles that exist in the Qur'an which all the other human beings and creature are not able to compose a work like the Qur'an although it is only one verse, and this challenge is valid until the end of the world, even till now proven, no one can do it.

\section{c.Qada 'and Qadar of Lord}

Basically Qada 'and Qadar are one of six pillars of faith as explained by Gabriel when meeting the Prophet. According to al-Ash'ari, Qada 'and Qadar is a inevitability of Lord that must be profoundly believed by all Moslems, either the kindness that is ordered to be done, or the badiness that is forbidden to be done. Interesting things to note here, al-Ash'ari argues that Lord creates good and bad for human and His creature. But He insists that badness is the result of Lord's creation and all badness is forbidden by Lord and must be shunned while the good is the command of Lord and it is recommended to be done.

According to al-Maturidi, to know the teachings of religion is need two tools that are very urgent to be used, namely hearing $(a l$-sima') and mind ( $a l$-'aql), although the limits of knowledge is only on a global scope without further explanation of Intrinsic and specific. For the explanation of the essential and specific, humans need to use the power of taste, news, and musings. Here is a further explanation of al-Maturidi's theological concept. Qada 'and Qadar of Lord are one of the pillars of faith that must be believed by all Moslems. According to alMaturidi, Qada 'is Lord's decision on something and it is certain appropriate for him. The wisdom of the existence of Qada 'is the attainment of the essence of everything created in acting according to its role. Qadar is a measure of good and bad. Therefore, the measure is a certainty that must happen and will not be able to get out of it. The essence of believing in Qada 'and Qadar according to al-Maturidi is to believe in all the provisions and decisions of the Lord with all the inevitability attached to the decision, including the limits and the size of Lord concerning good and bad, information about rights and vanity, and consequences of Rewards and sins.

\section{Theology of M. Arsyad Thalib Lubis's Thought}

Therefore, in the field of theology, M.Arsyad Thalib Lubis always bases himself on the concept of theology led by al-Ash'ari and al-Maturidi named ahl Ahl al-Sunnah wa al-Jama'ah, especially in the field of the oneness and the traits of Lord, the Words of God and the relationship between mind and revelation, and the will of human linked with the Qada 'and the Qadar of Lord.

\section{a. The Oneness and Traits of Lord}

Al-Ash'ari and al-Maturidi agree that Lord is the One, and in His oneness, Lord has the traits of Qadim. In rationalizing it, both of them use logical proofs so that no one denies His unity. That is why even though both of them are figures who cling to the text, but making more value for them is both try to rationalize it with the medium of mind, although al-Maturidi surpasses al-Ash'ari in terms of systematization in thinking because of using hearing and mind in Accessing the truth of religion globally, then elaborate through the power of feeling, news, and deeper thinking. There are several things that distinguish between al-Ash'ari and al-Maturidi. besides the number of different traits, according to al-Maturidi there is the trait of Salbiyah, while al-Ash'ari does not discuss the trait of Salbiyah, between the two have differences in giving the status of Lord's traits. Both alAsh'ari and al-Maturidi agree that Lord has the hands, faces, and eyes. The difference, if al-Ash'ari asserts that these three traits are bi-lakayf (unquestioned) while the other is not, al-Maturidi explains that all of Lord's traits consist of nafsiyah, salbiyah, $m a$ 'Ani, and ma'nawiyah that are the traits of Lord that are bi lakayf because they 
refer to form, whereas Lord is not shaped. The concept of theology of M.Arsyad Thalib Lubis on the oneness of Lord and the traits escorted by al-Ash'ari and al-Maturidi is at first the basis of theology of M.Arsyad Thalib Lubis. When looking at the facts that occur in the field in the process of regeneration and education al washliyah, there is a very close relationship between the ideals and facts that occur, although some fields are not maximized and need to be improved.

Concretely, in the view of M.Arsyad Thalib Lubis generall, it has a match with the concept of theology of Ahl al-Sunnah wa al-Jama'ah version of al-'Ash'ari and al-Maturidi, but He does not mention the trait of ma'ani without any reason clear. Then, they do not discuss the traits of Lord about form of hands, face, and eyes. Although from the side of rationality, M.Arsyad Thalib Lubis has more value because he gives a considerable portion in explaining the traits of Lord and the concrete proofs.

The lack of rationalization on the traits of Lord also applies in the book 'Aqidat al-'Awam. This is understandable because the object of this book is usually addressed to students ibtida'iyah (elementary level). The different thing is if looking on the explanation of Husein Afandi in the book of al-Husun al-amidiyah. He explains in detail the evidence of Lord's traits. even he adds that all Moslems must know Lord's good traits such as wajib, jaiz or jaiz. This understanding will be easily obtained by understanding the laws of mind, such as 'aqli, impossible' aqli, and jaiz 'aqli.

\section{b. Regarding the Words of Allah and the Interaction between Revelation and Mind}

M.Arsyad Thalib Lubis As a pioneer of Ahl al-Sunnah wa al-Jama'ah, al-Ash'ari and al-Maturid agree that the Qur'an is words of Allah of Qadim. Then, what media can humans know that the Qur'an is the Kalam Allah of Qadim? Al-Ash'ari explains that it is only by using mind the human can know it. The human mind is Lord's gift to know everything that Lord and His Messenger preach. Al-Maturidi adds, to know it is not enough with mind only. Media is able to know the Qur'an is through hearing and mind although the knowledge obtained is only global. Through both (mind and hearing) of humans are able to understand the truths and badness described by the Qur'an globally. To know more details of the ultimate truth and ugliness, humans have additional media in the form of senses, khabar, and thinking. The dialectic of thinking from the theological concept of M.Arsyad Thalib Lubis affects the development of theology in Al-washliyah. The good thing is when those ideals have a match with the fact that M.Arsyad Thalib Lubis is able to apply these great ideals to the fact of cadreisation and education of al washliyah, although here and there are still some shortcomings that need to be fixed. In the view of M.Arsyad Thalib Lubis, that the proof of the Qadim of the Qur'an is a miracle contained in it, so that no one is able to make or compare the greatness of Lordthrough this Qur'an. To know the entire contents of the Qur'an as well as his miracles is through mind. The same thing is true of 'Aqidat al-'Awam book, the work of Ahmad Marzuki and the book of al-Habib al-Hamidiyah by Husein Muhammad. Then Ahmad Marzuki adds that Lord's Word is sometimes heard by Lord himself and sometimes delivered through the Gabriel but what is certain is that Lord's words of azali (Qadim) and is sent without letters and sounds (bi laharf wa lasawt).

\section{Qada 'and Qadar of God and The Will of Human Free}

Both al-Ash'ari and al-Maturidi argue that Qada 'and the Qadar of Lord are a necessity that has been determined in the days of azali, either good deeds or bad deeds. But it needs to be emphasized here, humans are free to choose between doing good and bad that is also responsible for the consequences of that choice. If you choose evil, he is advised to always repent and not repeat again. if he is not repent, the door of hell is very wide opened for him. On the contrary, if man prefers good deeds in his life, Allah promises a paradise whose enjoyment cannot be conceived by the five senses. The great ideals of this theological concept are far different from the fact al washliyah at the stage of cadre and education. The concept of Qada 'and Qadar by M.Arsyad Thalib Lubis is more inclined to the concept of al-Ash'ari and al-Maturidi that give ikhtiyar and kasb for human beings. This is same thing with Qada 'Qadar concept in the book' Aqidat al-'Awam and al-Husun al-Hamidiyah which is more similar to the concept of al-Ash'ari and al-Maturidi although there are still divides that distinguish at the stage of rationalization.

\section{CONCLUSION}

Ijtihad of H.M. Arsyad Thalib Lubis covers many fields such as the field of Islamic law (fiqh), theology and the benefit of the people (life). Special thought of H.M.Arsyad Thalib Lubis about Islamic law (fiqh) has a pattern of Indonesian. So that becomes islamic fiqh Indonesia. He is very open with the opinions of the Mujtahid even though he is Shafi'iyah (followers of Shafi'i). Personal of H.M.A is a fairly popular personal. He can be accepted by all parties because it successfully presents itself as a figure having a high integrity of science, and proves all the concepts of Islamic life in daily practice. In the context of Furu'(jurisprudence) H. M. Arsyad Thalib Lubis is indeed tolerant. This tolerant attitude arises from the depth and breadth of his knowledge about Islamic teachings. Unlike most of people at that time who are fanatical and rigid about fiqih believed by others. 


\section{REFERENCES}

[1] Al-Asy'ari, al-Ibanah 'an Ushul al-Diyanah, (Kairo: Idarah al-Thiba'ah al- Muniriyyah, tt.)

[2] Al-'Amidi, Safyuddin, Ghayah al-Maram fi 'Ilm al-Kalam, (Kairo: Majlis al-A'la Li Syu'un alIslamiyyah, 1971)

[4] Ali, Mohammad Daud, Hukum Islam, Pengantar Ilmu Hukum dan Tata Hukum Islam (Jakarta: Raja Grafindo Persada, 1996)

[6] Al-Juwayni, al-Burhan Fi Ushul al-Fiqh, Juz I, (Kairo: Dar al-Anshar, tt.)

[7] Basyir, Ahmad Azhar, Pokok-Pokok Ijtihad dalam Hukum Islam, dalam Jalalluddin Rahmat,

Editor,Ijtihad dalam Sorotan, (Bandung: Penerbit Mizan, 1994)

[8] Beck, H.L. dan N.J.G. Kaptein (Redaktur), dalam Pandangan Barat Terhadap Literatur, Hukum, Fiolosofi, Teologi dan Mistik Tradisi Islam, (Jakarta: Indonesian- $\quad$ Netherlands Cooperation in Islamic Studies, 1988)

[9] Bik, Muhammad Khudari,Usul al-Fiqh. (Beirut: Dar al-Fikr, 1981)

[10] Dhuraib, Sa'ud ibn Sa'd Ali, al-Tanzhim al-Qadha'i fi al-Mamlakah al-'Arabiyyah alSu'udiyyah, (Riyadh: Mathabi' Hanifah Li al-Ubset, 1073 H)

[11] Djatnika, Rahmat, Perkembangan Ilmu Fikih di Dunia Islam, (Jakarta: Bumi Aksara, 1992)

[12] Glasse, Cyrill, The Concise Encyclopedia of Islam, (London: Stacey International, 1989)

[13] Hanafi, Ahmad Pengantar dan Sejarah Hukum Islam (Jakarta: Bulan Bintang, 1970)

[14] Haq, Hamka, Al-Syatibi, Aspek Teologis Konsep Maslahah dalam Kitab Al- Muwafaqat, (Jakarta: Erlangga, 2007)

[15] Harahap, Syahrin, Studi Tokoh Dalam Bidang Pemikiran Islam, (Medan: Pusat Penelitian IAINSU,1995)

[16] Hasan, Ahmad, The Early Development of Islamic Jurisprudence, (Islamabad: Islimic Research Institute, 1970)

[17] Hasanuddin, Chalidjah Al-Jam 'iyatul Washliyah; Api Dalam Sekam (Bandung: Pustaka, 1988)

[18] Hasballah, Thaib, Manusia Dalam Pandangan H. M. Arsyad Thalib Lubis, (Medan: $\quad$ LPP Best Komputer, 1997)

[19] - --------, Syeikh H.M. Arsyad Thalib Lubis: Pemikiran dan Karya Monumental, (Medan: Perdana Publishing,2012)

[20] Iqbal, M., Hukum Islam Indonesia Modern (Tangerang: Gaya Media Pratama,2009)

[21] Khaldun, Ibnu, Muqaddimah, (Mesir: Mathba'ah Musthafa Muhammad, tt.)

[22] Khallaf, Abdul Wahab, Ushul Fiqh, (Mesir: Litthiba'ah wa al-Nasr wa al-Tauzi',

[23] Krippendroff, Klaus, Content Analysis : Introduction to Its Theory, terj. Oleh Farij Analisis Isi, Pengantar Teori dan Metodologi, (Jakarta: Rajawali Press, 1991)

[24] Lubis, M. Arsyad Thalib, Al-Fatawa, Fatwa Beberapa Masalah, (Medan: Firma Islamiyah, 1982)

$$
\text { Isth }
$$

, Ilmu Fikih, ( Medan: Firma Islamiyah, 1968)

, Ilmu Pembagian Pusaka, (Medan; Firma Islamiyah, 1967)

Ushul Figh, (Medan: Univa,1989) al-ushul min 'ilm al-ushul, (Medan: Sumber ilmu,1960)

, Debat Islam-Kristen tentang Kitab Suci, (Jakarta: PB

Penuntun Perang Sabil, (Medan: Firma Maju, 1957)

, Pelajaran Iman, (Medan: Firma Islamiyah, 1975)

Imam Mahdi,(Medan: Firma Islamiyah, 1967)

,Keesaan Tuhan, (Jakarta: Dewan Dakwah Islamiyah Indonesia,

'Muhammad, Abbas Husni, al-Fiqh al-Islami, Afaquh wa Tathawwuruhu, (Mekkah:

1972)

'Alam al-Islami, $1402 \mathrm{H}$ )

[35] Lubis, Nur ahmad Fadhil, Hukum Islam dalam Kerangka Teori Fiqh dan Tata Hukum (Medan: Pustaka Widyasarana, 1995)

[36] Ma'luf, Louis, Al-Munjid fi al-Lughat wa al-A 'lam, (Beirut: Dar al-Masyriq, t.t.)

[37] Nasution, Harun, Teologi Islam Aliran-aliran Sejarah Analisa Perbandingan, (Jakarta: UI Press, 1986)

[38] _ _ Islam Ditinjau dari Berbagai Aspeknya (Jakarta: UI Press, 1986)

[39] Nasution, M. Yasir, Hukum Islam dan Signifikansinya dalam Kehidupan Masyarakat

Pidato Pengukuhan Guru Besar IAIN SU Medan tanggal 7 Januari 1995

[40] Nata, Abudin, Metodologi Studi Islam, (Jakarta: Raja Grafindo Persada, 1998) 
[41] Qaradhawi, Yusuf, al-Madkhal li Dirasat al-Syari'ah al-Islamiyah, (Kairo: Maktabah wahbah, 1990)

[42] Rafiq, Ahmad, Hukum Islam di Indonesia, (Jakarta: Raja Grafindo Persada, 1995)

[43] Rahman, Fazlur, Islam, (London: University of Chicago Press, 1979)

[44] _ _ Islamic Methodology In History, Terj. oleh Anas Mahyuddin, Membuka (Bandung: Penerbit Pustaka, 1984)

[45] _ Post Formative Developments in Islam. (Karachi: Islamic Studies,

Pintu Ijtihad,

[46] Ramadhan, Said, Islamic Law its scope and Equity (Kuala lumpur: Muslim Youth Malaysia, 1987)

[47] Rusli, Nasrun Konsep Ijtihad asy-Syaukani (Jakarta: Logos Wacana Ilmu, 1999)

[48] Soekanto, Soerjono, Pengantar Peneltian Hukum, (Jakarta: UI Press, 1986)

[49] Sukiman, Biografi Ulama Nusantara: Profil H.M. Arsyad Thalib Lubis, Refleksi Kifrahnya $d i$ Sumatera Utara, (Jakarta: Proyek Puslitbang Lektur dan Khazanah Keagamaan badang Litbang dan diklat kementerian Agama RI, 2012)

[50] Tawana, Muhammad Musa, al-Ijtihad: Madha Hajatina Ilaihi fi Hadha al- 'Asr. (Dar al-Kutub alHadithah, 1972)

[51] Zahrah, Muhammad Abu, Ushul Fiqh, (t.tp., Dar al-Fikri al-‘Arabi, 1958) 